\title{
Preparedness to Tackle Coronavirus and Its Risk Perceptions among Health Care Professionals in Chennai City, India - A Cross-Sectional Study
}

\author{
Suganya. $\mathbf{P}^{1}$, Sindhu. $\mathbf{R}^{2}$, Dinesh Dhamodhar ${ }^{3}$, Shreelakshmi. $\mathbf{S}^{2}$, Prabu. $\mathbf{D}^{4}$, \\ Rajmohan. $\mathbf{M}^{3}$, Bharathwaj. V. ${ }^{2}$, Prashanthy. M. $\mathbf{R}^{1}$ \\ ${ }^{1}$ Postgraduate Student, Department of Public Health Dentistry, SRM Dental College and Hospital, Ramapuram \\ ${ }^{2}$ Senior Lecturer, Department of Public Health Dentistry, SRM Dental College and Hospital, Ramapuram \\ ${ }^{3}$ Reader, Department of Public Health Dentistry, SRM Dental College and Hospital, Ramapuram \\ ${ }^{4}$ Head and Professor of the department, Department of Public Health Dentistry, SRM Dental College and \\ Hospital, Ramapuram \\ Corresponding Author: Prabu. D
}

\begin{abstract}
Background: Coronavirus (COVID-19) is an infectious disease which begins to spread rapidly in various parts of the world including India. The health care professionals play a pivotal role in preventing or managing this disease so it is very essential for them to have an adequate knowledge, attitude and practice in tackling the disease.
\end{abstract}

Aim: This study aims to evaluate the preparedness to tackle coronavirus and its risk perceptions among health care professionals in Chennai city, India.

Materials and Methods: A cross-sectional study was conducted among 133 health care professionals in Chennai city. A sample of 67 medical and 66 dental professionals were selected from various hospitals in Chennai city based on the simple random sampling method. The questionnaire consists of 33 items regarding knowledge, attitude and practice towards coronavirus (COVID-19) and its risk perceptions among medical and dental health care professionals were obtained. The data was analyzed by using chi square test. $\mathrm{P}$ value $<0.05$ was considered to be a statistically significant.

Results: The statistically significant difference was found regarding knowledge of symptoms, diagnosis of coronavirus among medical and dental professionals $(p=0.0005)$. There was a highly significant difference was found among medical professionals regarding about the coronavirus WHO guidelines and proper facilities in treating coronavirus between medical and dental professionals $(p=0.0005)$. The risk perceptions of medical professionals towards coronavirus were found to be statistically significant when compared to dental professionals ( $\mathrm{p}>0.0005)$.

Conclusion: The medical professionals have an adequate knowledge, attitude, practice and risk perceptions towards coronavirus when compared to dental professionals.

Keywords: Coronavirus, Health care professionals, Knowledge, Attitude, Practice, Risk perceptions.

\section{INTRODUCTION}

Coronavirus is one of the most infectious emerging disease which affects the respiratory tract of humans. The corona virus strains which infected human beings before COVID-19 are SARS- CoV (severe acute respiratory syndrome corona virus) and MERS-CoV (Middle East respiratory syndrome corona virus ${ }^{[1]}$.

The current outbreak of Novel coronavirus (COVID-19) was first emerged in Wuhan, China on $31^{\text {st }}$ December 2019, then it starts spreads to other countries throughout the world including. World Health Organization had declared this outbreak as a public health emergency concern on $30^{\text {th }}$ January 2020 . The term 
COVID-19 for this virus was given by WHO on February $11^{\text {th }} 2020$ [2] WHO announced coronavirus outbreak as pandemic on $11^{\text {th }}$ March 2020. Previously two strains of corona virus such as Severe Acute Respiratory Syndrome Coronavirus (SARS- CoV) and Middle East Respiratory Syndrome (MERS- CoV) have infected human begins but the only strain Novel coronavirus (COVID- 19) is found to be pandemic ${ }^{[2,3]}$.

The outbreak of coronavirus (COVID-19) begins to spread in India with the first case confirmed in Kerala on $30^{\text {th }}$ January 2020 and then it slowly starts spreading to various parts of India. The symptoms include coughing; running nose, sore throat, sneezing and sometimes fever is also reported ${ }^{[4]}$.

World Health Organization (WHO) has updated a guideline to reduce the spread of corona virus infection which involves washing hands with soap and water. The preferred element is frequent washing of hands with soap and water and if soap and water is not available, use alcohol-based hand rub, cover the nose while sneezing and coughing to avoid the spread of infection, avoid close contact with person having cold or flu like syndrome and avoid contact with wild or farm animals or visiting live or wet market. The incubation of coronavirus is 5 days and approximately 2-14 days. Since coronavirus starts with mild symptoms, they are several cases reported among children in Shenzhen, china that they do not have symptoms but developed coronavirus ${ }^{[5] \text {. }}$

WHO is working closely with global experts, governments and partners to rapidly expand scientific knowledge on this new virus, to track the spread and virulence of the virus, and to provide advice to countries and individuals on measures to protect health and prevent the spread of this disease. To overcome this situation the health care professionals should have adequate knowledge to tackle the corona virus. Various studies have been conducted regarding the knowledge and awareness of coronavirus among the public and health care professionals during SARS $\mathrm{CoV}$ and MERS CoV in Saudi Arabia ${ }^{[6-10]}$. None of the studies have been considered about the risk perceptions of health care professionals related to corona virus out breaks.

Moreover, in India no studies have been conducted concerning the tackiness of corona virus among the health care professionals. So, this present study deals to evaluate the preparedness to tackle the coronavirus and its risk perceptions among health care professionals.

\section{MATERIALS AND METHODS}

A descriptive, cross-sectional study was conducted among health care professionals to evaluate the preparedness to tackle coronavirus and its risk perception among health care professionals in Chennai city. The sample size was calculated to be 133 by setting a confidence level $95 \%$ and the margin of error $5 \%$ based on the previous study conducted by Varghese et al in the year $2019^{[11]}$.

The ethical approval was obtained from the Institutional Review Board of SRM dental college, Ramapuram (SRMU/M\&HS/SRMDC/2020/PG/001). A sample of 67 medical and 66 dental health care professionals were randomly selected from various hospitals in Chennai city based on the simple random sampling by using lottery method and the study was conducted for a period of 1month i.e., in January 2020.

The inclusion criteria of this study include only medical and dental health care professionals who were qualified with at least undergraduate medical or dental degree were selected. The subjects who were willing to participate and those who fulfill the consent form were included. Those subjects who didn't fulfill the questionnaire were excluded from the study.

The pilot study was conducted among 10 medical and 10 dental professionals based on the convenience sampling method and the questionnaire was distributed to them. The questionnaire consists of 40 items were pretested and validated to check the internal consistency 
Suganya. P et.al. Preparedness to tackle coronavirus and its risk perceptions among health care professionals in Chennai city, India - a cross-sectional study.

using Cronbach's alpha (0.83) which was found to be good [12, 13]. The questions which outfits and ambiguous to the study were excluded and the final performa of the questionnaire were prepared to minimize bias. The subjects who participated in the pilot study were excluded from the main study.

The finally prepared 33 questionnaire was distributed among 67 medical and 66 dental health care professionals. The questionnaire consists of four domains the first part based on knowledge of coronavirus regarding symptoms, laboratory testing, mode of transmission, vaccine/ medication available for corona virus, onset of disease and preventive procedures for coronavirus, the second part focused on the attitude of health care professionals towards coronavirus such as washing hands, seeking additional information about coronavirus, consuming more nutritional foods and water than before and avoid going to crowd places, the third one based on the practice of health care professionals in tackling coronavirus which includes symptoms, preventive procedures, diagnostic tests, suspected patients to be treated in isolated closed rooms, etc and the fourth part focused on their risk perceptions towards the disease such as avoidance of patents, acceptance of risk, control, fear and job change. The data were entered and interpreted using the IBM Statistical Package for the Social Sciences 23.0 (IBM Corp., Armonk, New York). The data was then analyzed by using chi square test. $\mathrm{P}<$ 0.05 was considered to be statistically significant.

\section{RESULTS}

Medical professionals have a good level of knowledge, attitude and practice in tackling the coronavirus when compared to dental professionals. The medical professionals have a higher risk perception towards coronavirus when compared to dental professionals.

\begin{tabular}{|c|c|c|c|c|c|c|c|}
\hline \multirow[t]{2}{*}{$\begin{array}{l}\text { Questionnaire } \quad \text { regarding } \\
\text { knowledge of coronavirus }\end{array}$} & \multicolumn{3}{|c|}{$\begin{array}{l}\text { Total no. of percentage responses among } \\
\text { dental professionals }\end{array}$} & \multicolumn{3}{|c|}{$\begin{array}{l}\text { Total no. of percentage responses of } \\
\text { medical professionals }\end{array}$} & \multirow[t]{2}{*}{ P value } \\
\hline & Yes & No & Don't know & Yes & No & Don't know & \\
\hline $\begin{array}{l}\text { 1.Have you been aware of corona } \\
\text { virus? }\end{array}$ & $66(100 \%)$ & 0 & 0 & $67(100 \%)$ & 0 & 0 & $\begin{array}{l}\text { Not } \\
\text { applicable }\end{array}$ \\
\hline $\begin{array}{l}\text { 2. Is corona virus a respiratory } \\
\text { disease? }\end{array}$ & $66(100 \%)$ & 0 & 0 & $67(100 \%)$ & 0 & 0 & $\begin{array}{l}\text { Not } \\
\text { applicable }\end{array}$ \\
\hline $\begin{array}{l}\text { 3. Do you think fever, cough and } \\
\text { difficulty in breathing are the } \\
\text { common symptoms of } \\
\text { coronavirus? }\end{array}$ & $55(83.3 \%)$ & $11(16.7 \%)$ & 0 & $67(100 \%)$ & 0 & 0 & $0.0005^{*}$ \\
\hline $\begin{array}{l}\text { 4. Can diagnosis of coronavirus } \\
\text { be confirmed by laboratory } \\
\text { testing of a respiratory sample? }\end{array}$ & $35(53.0 \%)$ & $9(13.6 \%)$ & $22(33.3 \%)$ & $67(100 \%)$ & 0 & 0 & $0.0005^{*}$ \\
\hline 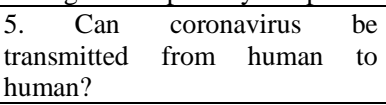 & $57 \%$ & 0 & $9(13.6 \%)$ & $50(74.6 \%)$ & 0 & $17(25.4 \%)$ & 0.088 \\
\hline $\begin{array}{l}6 . \quad \text { Is there any } \\
\text { vaccine/medication available for } \\
\text { coronavirus? }\end{array}$ & $12(18.2 \%)$ & $33(50.0 \%)$ & $21(31.8 \%)$ & $31(46.3 \%)$ & $25(37.3 \%)$ & $11(16.4 \%)$ & $0.002 *$ \\
\hline 7. Can coronavirus causes death? & $49(74.2 \%)$ & $10(15.2 \%)$ & $7(10.6 \%)$ & $43(64.2 \%)$ & 0 & $24(35.8 \%)$ & $0.0001^{*}$ \\
\hline $\begin{array}{l}\text { 8. Is coronavirus recurrent in } \\
\text { human beings? }\end{array}$ & $21(31.8 \%)$ & $7(10.6 \%)$ & $38(57.6 \%)$ & $15(22.4 \%)$ & $13(19.4 \%)$ & $39(58.2 \%)$ & 0.246 \\
\hline $\begin{array}{l}\text { 9.Is the coronavirus samples } \\
\text { testing laboratory facilities } \\
\text { available in Chennai? }\end{array}$ & 13(19.7\%) & $22(33.3 \%)$ & $31(47.0 \%$ & $27(40.3 \%)$ & $40(59.7 \%)$ & 0 & $0.0005^{*}$ \\
\hline $\begin{array}{l}\text { 10. Do you think that washing } \\
\text { hands regularly will reduce the } \\
\text { infection? }\end{array}$ & $53(80.3 \%)$ & 0 & 13(19.7\%) & $45(67.2 \%)$ & 0 & $22(32.8 \%)$ & 0.085 \\
\hline $\begin{array}{l}\text { 11. Do you know how long the } \\
\text { symptoms take to appear after } \\
\text { being exposed to corona virus? }\end{array}$ & $37(56.1 \%)$ & 0 & 29(43.9\%) & $54(80.6 \%)$ & 0 & 13(19.4\%) & $0.002 *$ \\
\hline
\end{tabular}

Note ( ${ }^{*} p<0.05$ is found to be statistically significant)

Table 1 shows about the knowledge of corona virus among medical and dental health care professionals. Out of 133 health care professionals, the 55 number of dental 
Suganya. P et.al. Preparedness to tackle coronavirus and its risk perceptions among health care professionals in Chennai city, India - a cross-sectional study.

professionals (83.3\%) and 67 number of medical professionals $(100 \%)$ had an adequate knowledge regarding the symptoms of corona virus and it was found to be statistically significant $(\mathrm{p}=0.0005)$. The 35 number of dental professionals $(53.0 \%)$ and 67 number of medical professionals $(100 \%)$ had an adequate knowledge laboratory diagnosis of coronavirus and it was found to be statistically significant $(\mathrm{p}=0.0005)$. The 12 number of dental professionals (18.2\%) and 31 number of medical professionals (46.3\%) had a good knowledge regarding vaccine/medication of corona virus and it was found to be statistically significant $(\mathrm{p}=0.002)$. The 49 number of dental professionals (74.2\%) and 43 number of medical professionals (64.2\%) had responded that the coronavirus causes death and it was found to be statistically significant $(\mathrm{p}=0.0001)$. The 13 number of dental professionals (19.7\%) and 27 number of medical professionals (40.3\%) had responded that the coronavirus testing laboratory facilities available in Chennai and it was found to be statistically significant $(\mathrm{p}=0.0005)$. The 37 number of dental professionals (56.1\%) and 54 number of medical professionals (80.6\%) had a good knowledge regarding the time period of symptoms takes to appear after being exposed with the disease and it was statistically significant $(\mathrm{p}=0.002)$.

TABLE 2: ATTITUDE OF HEALTH CARE PROFFESIONALS AFTER GETIING TO KNOW CORONAVIRUS OUTBREAK

\begin{tabular}{|c|c|c|c|c|c|}
\hline \multirow{2}{*}{$\begin{array}{l}\text { Questionnaire regarding } \\
\text { attitude of coronavirus After } \\
\text { getting to know corona virus }\end{array}$} & \multicolumn{2}{|c|}{$\begin{array}{l}\text { Total no. of percentage responses among } \\
\text { dental professionals }\end{array}$} & \multicolumn{2}{|c|}{$\begin{array}{l}\text { Total no. of percentage responses among } \\
\text { medical professionals }\end{array}$} & \multirow[t]{2}{*}{$\begin{array}{l}\mathbf{P} \\
\text { value }\end{array}$} \\
\hline & Yes & No & Yes & No & \\
\hline $\begin{array}{l}\text { 1.Do you wash your hands more } \\
\text { frequently than before? }\end{array}$ & $37(56.1 \%)$ & $29(43.9 \%)$ & $47(70.1 \%)$ & $20(29.9 \%)$ & 0.092 \\
\hline $\begin{array}{l}\text { 2. Do you seek for additional } \\
\text { information } \\
\text { coronavirus? }\end{array}$ & $47(71.2 \%)$ & $19(28.8 \%)$ & $48(71.6 \%)$ & $19(28.4 \%)$ & 0.956 \\
\hline $\begin{array}{l}\text { 3. Consume more nutritional } \\
\text { food than before? }\end{array}$ & $28(42.4 \%)$ & $38(57.6 \%)$ & 12(17.9\%) & 55(82.1\%) & $0.002 *$ \\
\hline $\begin{array}{l}\text { 4. Drink plenty of water than } \\
\text { before? }\end{array}$ & $16(24.2 \%)$ & $50(75.8 \%)$ & $32(47.8 \%)$ & $35(52.2 \%)$ & $0.005^{*}$ \\
\hline $\begin{array}{l}\text { 5. Do you avoid going to crowd } \\
\text { places? }\end{array}$ & $31(47.0 \%)$ & $35(53.0 \%)$ & $27(40.3 \%)$ & $40(59.7 \%)$ & 0.438 \\
\hline
\end{tabular}

Note $(* P<0.05$ is found to be statistically significant)

Table 2 shows about the attitude of health care professionals after getting to know coronavirus outbreak. Out of 133 health care professionals, the 28 number of dental professionals (42.4\%) and 12 number of medical professionals (17.9) had a consumed more nutritional food than before and it was found to be statistically significant $(\mathrm{p}=0.002)$ whereas the 16 number of dental professionals (24.2\%) and 32 number of medical professionals (47.8\%) had consumed more water than before and it was found to be statistically significant $(\mathrm{p}=0.005)$.

Table 3 shows about the practice of health care professionals to tackle the coronavirus. Out of 133 health care professionals the 15 number of dental professionals (22.7\%) and 39 number of medical professionals (58.2\%) have read about the WHO/CDC guidelines to treat coronavirus and it was found to be statistically significant $(\mathrm{p}=0.0005)$. The 10 number of dental professionals $(15.2 \%)$ and 57 number of medical professionals (85.1\%) had responded that their clinic/hospital/health care specialties had proper facilities in managing the coronavirus patients and it was found to be statistically significant $(\mathrm{p}=0.0005)$. The 58 number of dental professionals (87.9\%) and 67 number of medical professionals (100\%) had responded that the coronavirus suspected patients should be treated in Air borne infection isolation room (AIIR) and it was found to be statistically significant $(p=0.003)$. The 23 number of dental professionals (34.8\%) and 50 number of medical professionals (74.6\%) had responded that the corona virus infected person should be kept in closed room and it 
Suganya. P et.al. Preparedness to tackle coronavirus and its risk perceptions among health care professionals in Chennai city, India - a cross-sectional study.

was found to be statistically significant $\quad(p=0.0005)$.

TABLE 3: PRACTICE OF HEALTH CARE PROFESSIONALS TO TACKLE CORONAVIRUS

\begin{tabular}{|c|c|c|c|c|c|}
\hline \multirow[t]{2}{*}{$\begin{array}{l}\text { Questionnaire regarding practice to handle } \\
\text { coronavirus }\end{array}$} & \multicolumn{2}{|c|}{$\begin{array}{l}\text { Total no. of percentage responses } \\
\text { among dental professionals }\end{array}$} & \multicolumn{2}{|c|}{$\begin{array}{l}\text { Total no. of percentage responses } \\
\text { among medical professionals }\end{array}$} & \multirow[t]{2}{*}{ P value } \\
\hline & Yes & No & Yes & No & \\
\hline $\begin{array}{l}\text { 1.Have you ever diagnosed or referred a case of } \\
\text { coronavirus? }\end{array}$ & 0 & $66(100 \%)$ & 0 & $67(100 \%)$ & $\begin{array}{l}\text { Not } \\
\text { applicable }\end{array}$ \\
\hline $\begin{array}{l}\text { 2. Have you read about the WHO/CDC } \\
\text { standard guidelines to handle coronavirus? }\end{array}$ & $15(22.7 \%)$ & $51(77.3 \%)$ & $39(58.2 \%)$ & $28(41.8 \%)$ & $0.0005^{*}$ \\
\hline $\begin{array}{l}\text { 3. Personnal protective equipment to be used } \\
\text { when seeing suspected cases of coronavirus? }\end{array}$ & $40(60.6 \%)$ & $26(39.4 \%)$ & $82(61.7 \%)$ & $51(38.3 \%)$ & 0.805 \\
\hline $\begin{array}{l}\text { 4. Is your clinic/hospital/health care specialities } \\
\text { have proper facilities in managing coronavirus? }\end{array}$ & $10(15.2 \%)$ & $56(84.8 \%)$ & $57(85.1 \%)$ & $10(14.9 \%)$ & $0.0005^{*}$ \\
\hline $\begin{array}{l}\text { 5. Most important standard precaution that } \\
\text { should be applied when seeing a case of } \\
\text { coronavirus }\end{array}$ & $43(65.2 \%)$ & $23(34.8 \%)$ & $47(70.1 \%)$ & $20(29.9 \%)$ & 0.538 \\
\hline $\begin{array}{l}\text { 6. What should be done after discharge of } \\
\text { coronavirus infected patient? }\end{array}$ & $\begin{array}{l}\text { Correct } \\
\text { responses- } \\
50(75.8 \%) \\
\end{array}$ & $\begin{array}{l}\text { Incorrect } \\
\text { responses- } \\
16(24.2 \%) \\
\end{array}$ & $\begin{array}{l}\text { Correct } \\
\text { responses- } \\
52(77.6 \%) \\
\end{array}$ & $\begin{array}{l}\text { Incorrect } \\
\text { responses- } \\
15(22.4 \%) \\
\end{array}$ & 0.800 \\
\hline $\begin{array}{l}\text { 7. Do you think that the suspected patient with } \\
\text { coronavirus should be treated in Air borne } \\
\text { infection isolation room (AIIR)? }\end{array}$ & $58(87.9 \%)$ & $8(12.1 \%)$ & $67(100 \%)$ & 0 & $0.003^{*}$ \\
\hline 8. Diagnostic test to be used for coronavirus? & $\begin{array}{l}\text { Correct } \\
\text { responses- } \\
27(40.9 \%) \\
\end{array}$ & $\begin{array}{l}\text { Incorrect } \\
\text { responses- } \\
39(59.1 \% 0 \\
\end{array}$ & $\begin{array}{l}\text { Correct } \\
\text { responses- } \\
35(52.2 \%) \\
\end{array}$ & $\begin{array}{l}\text { Incorrect } \\
\text { responses- } \\
32(47.8 \%) \\
\end{array}$ & 0.190 \\
\hline $\begin{array}{l}\text { 9. Carefully handle suspected patients' } \\
\text { belongings? }\end{array}$ & $66(100 \%)$ & 0 & $67(100 \%)$ & 0 & $\begin{array}{l}\text { Not } \\
\text { applicable }\end{array}$ \\
\hline $\begin{array}{l}\text { 10. Used to educate the clients about the } \\
\text { disease? }\end{array}$ & $40(60.6 \%)$ & $26(39.4 \%)$ & 49(73.1\%) & $18(26.9 \%)$ & 0.125 \\
\hline $\begin{array}{l}\text { 11. Which is the best hand wash to be } \\
\text { followed? }\end{array}$ & $\begin{array}{l}\text { Correct } \\
\text { responses- } \\
38(57.6 \%) \\
\end{array}$ & $\begin{array}{l}\text { Incorrect } \\
\text { responses- } \\
28(42.4 \%) \\
\end{array}$ & $\begin{array}{l}\text { Correct } \\
\text { responses- } \\
47(70.1 \%) \\
\end{array}$ & $\begin{array}{l}\text { Incorrect } \\
\text { responses- } \\
20(29.9 \%) \\
\end{array}$ & 0.131 \\
\hline $\begin{array}{l}\text { 12. Is it mandatory to place the corona infected } \\
\text { person in the closed room? }\end{array}$ & $23(34.8 \%)$ & $43(65.2 \%)$ & $50(74.6 \%)$ & $17(25.4 \%)$ & $0.0005 *$ \\
\hline
\end{tabular}

Note $(* P<0.05$ is found to be statistically significant)

TABLE 4: RISK PERCEPTIONS OF HEALTH CARE PROFESSIONALS TOWARDS CORONAVIRUS

\begin{tabular}{|l|l|l|l|l|l|}
\hline \multirow{2}{*}{$\begin{array}{l}\text { Questionnaire regarding risk } \\
\text { perceptions to coronavirus }\end{array}$} & $\begin{array}{l}\text { Total no. of percentage responses } \\
\text { among dental professionals }\end{array}$ & \multicolumn{2}{l|}{$\begin{array}{l}\text { Total no. of percentage responses among } \\
\text { medical professionals }\end{array}$} & P value \\
\cline { 2 - 5 } & Yes & No & Yes & \\
\hline $\begin{array}{l}\text { 1.Do you feel that you shouldn't be } \\
\text { looking after patients with } \\
\text { coronavirus? }\end{array}$ & $21(31.8 \%)$ & $45(68.2 \%)$ & $54(80.6 \%)$ & $13(19.4 \%)$ & $0.0005^{*}$ \\
\hline $\begin{array}{l}\text { 2. Do you accept the risk of getting } \\
\text { coronavirus? }\end{array}$ & $19(28.8 \%)$ & $47(71.2 \%)$ & $51(76.1 \%)$ & $16(23.9 \%)$ & $0.0005^{*}$ \\
\hline $\begin{array}{l}\text { 3. Do you have little control over } \\
\text { whether you get infected or not? }\end{array}$ & $33(50.0 \%)$ & $33(50.0 \%)$ & $58(86.8 \%)$ & $9(13.4 \%)$ & $0.0005^{*}$ \\
\hline $\begin{array}{l}\text { 4. Are you afraid of falling ill with } \\
\text { coronavirus? }\end{array}$ & $44(66.7 \%)$ & $22(33.3 \%)$ & $14(20.9 \%)$ & $53(79.1 \%)$ & $0.0005^{*}$ \\
\hline $\begin{array}{l}\text { 5. Are you looking for another job or } \\
\text { consider resigning because of the risk? }\end{array}$ & 0 & $66(100 \%)$ & 0 & $67(100 \%)$ & $\begin{array}{l}\text { Not } \\
\text { applicable }\end{array}$ \\
\hline
\end{tabular}

Note $\left({ }^{*} P<0.05\right.$ is found to be statistically significant)

Table 4 has discussed about the risk perceptions of health care professionals towards coronavirus. The medical professionals have a greater level of risk perceptions when compared to dental health professionals. The 21 number of dental professionals $31.8 \%$ and 54 number of medical professionals (80.6\%) avoided the patients infected with coronavirus. The 19 number of dental (28.8\%) and 51of medical professionals (76.1\%) had accepted the risk towards the disease. The 33 number of dental (50.0\%) and 58 of medical professionals (86.8\%) had a control over of getting infected whereas the 44 number of dental $(66.7 \%)$ and 14 number of medical (20.9\%) had a fear of getting the disease. There was a significant difference was found between medical and dental health care professionals regarding avoidance of patients, acceptance of risk, control over and fear of being infected with coronavirus $(p=0.0005)$. 


\section{DISCUSSION}

Coronavirus is an infectious disease emerging throughout the world. The health care professionals play a pivotal role in treating and managing the diseases so the health care professionals must have a proper knowledge and practice to handle the patients affected with coronavirus. Moreover, the health care professionals have a highest risk of being infected with the disease. Considering this controversy, this present study was conducted to assess the preparedness to tackle coronavirus and its risk perceptions among medical and dental health care professionals in Chennai city.

The medical health care professionals have a good level of knowledge regarding symptoms, onset of disease, medications and diagnostic tests when compared to dental health care professionals. The previous study conducted by Al-Amri et al in the year 2019 shows that primary health care physicians have a good level of knowledge regarding Middle East Respiratory Syndrome Coronavirus (MERSCoV) ${ }^{[12]}$.

The attitude of health care professionals after getting to know corona outbreak such as washing hands frequently, seeking additional information regarding the disease, avoid going to crowd places and consuming more nutritional foods and water. The dental health care professionals have a good level of attitude such as consuming more nutritional foods and avoid going to crowd places when compared to medical health care professionals. Both medical and dental professionals have a good level of attitude regarding washing hands frequently and seeking additional information of coronavirus.

Medical professionals have a better practice in tackling the coronavirus infected patients when compared to dental professionals. The previous study conducted by Assad et al discussed about the knowledge and attitude of health care workers towards MERS- $\mathrm{CoV}$ and concluded that health care workers have an adequate knowledge towards the disease ${ }^{[1]}$.

The study conducted by Imai et al has discussed about the risk perceptions of Severe Acute Respiratory Syndrome (SARS) among health care work workers in Japan and concluded that health care workers have higher risk perceptions towards the disease ${ }^{[13]}$.

In this study, the risk perceptions of health care professionals towards coronavirus such as avoiding the patient, accepting the risk, fear, control over and changing their job were assessed. The medical professionals have a higher risk perception towards corona virus when compared to dental professionals.

\section{Limitations:}

Further longitudinal studies should be conducted among larger populations to get more appropriate results. Moreover, there might be a chance of social desirability bias which affects the outcome of the study.

\section{CONCLUSION}

This study concludes that the medical professionals have more knowledge, attitude, practice and risk perceptions towards coronavirus when compared to dental health care professionals. The health care professionals should take appropriate measures to gain adequate knowledge and practice regarding corona virus to treat the patients in a more effective way.

\section{Acknowledgement: None}

\section{Conflict of Interest: None}

Source of Funding: None

Ethical Approval: Approved

\section{REFERENCES}

1. Asaad AM, El-Sokkary RH, Alzamanan MA, El-Shafei M. Knowledge and attitudes towards Middle East respiratory syndrome- 
Suganya. P et.al. Preparedness to tackle coronavirus and its risk perceptions among health care professionals in Chennai city, India - a cross-sectional study.

coronavirus (MERS-CoV) among health care workers in south-western Saudi Arabia. East Mediterr Health J. 2019;25.

2. Peng X, Xu X, Li Y, Cheng L, Zhou X, Ren B. Transmission routes of 2019-nCoV and controls in dental practice. International Journal of Oral Science. 2020 Mar 3;12(1):1-6.

3. WHO Director- General's opening remarks at the media briefing on COVID-19. [updated 2020 March 11; cited 2020 March 17]. Available from: https://www.who.int/dg/speeches/detail/who -director-general-s-opening-remarks-at-themedia-briefing-on-covid-19.

4. WHO. Novel coronavirus - China. Jan 12, $2020 . \quad$ http://www.who.int/csr/don/12january-2020-novel-coronavirus-china/en/ (accessed Jan19, 2020).

5. Assiri A, Al-Tawfiq JA, Al-Rabeeah AA, et al. Epidemiological, demographic, and clinical characteristics of 47 cases of Middle East respiratory syndrome coronavirus disease from Saudi Arabia: a descriptive study. Lancet Infect Dis 2013; 13: 752-61.

6. Memish ZA, Assiri A, Alhakeem R, Yezli S, Almasri M, Zumla A, Al- Tawfiq JA, Drosten C, Albarrak A, Petersen E. Middle East Respiratory Syndrome Corona virus, MERS-CoV. Conclusions from the $2^{\text {nd }}$ scientific advisory board meeting of the WHO collaborating center for mass gathering medicine, Riyadh. International Journal of Infectious Diseases. 2014 Jul 1;24:51-3.

7. Almutairi KM, Al Helih EM, Moussa M, Boshaiqah AE, Saleh Alajilan A, Vinluan JM, Almutairi A. Awareness, attitudes, and practices related to coronavirus pandemic among public in Saudi Arabia. Family \& community health. 2015 Oct 1;38(4):33240.

8. Al Mohaissen M. Awareness among a Saudi Arabian university community of Middle
East respiratory syndrome coronavirus following an outbreak. EMHJ-Eastern Mediterranean Health Journal. 2017;23(5):351-60.

9. Shammah A, Budoor H, Suad M, Richard K, Maha S, Asokan GV. Middle East Respiratory Syndrome Corona Virus (MERS-CoV): Levels of Knowledge and Awareness in Bahrain. KnE Life Sciences. 2018 Oct 15:98-114.

10. Althobaity HM, Alharthi RA, Altowairqi MH, Alsufyani ZA, Aloufi NS, Altowairqi AE, Alqahtani AS, Alzahrani AK, AbdelMoneim AS. Knowledge and awareness of Middle East respiratory syndrome coronavirus among Saudi and Non-Saudi Arabian pilgrims. International journal of health sciences. 2017 Nov;11(5):20.

11. Varghese AD, Mathew G, Kumar SC, Benjamin AI. Awareness regarding Nipah infection among health-care workers in a Medical College Hospital in Kerala. Journal of Current Research in Scientific Medicine. 2019 Jan 1;5(1):33.

12. Al-Amri S, Bharti $\mathrm{R}$, Alsaleem SA, AlMusa HM, Chaudhary S, Al-Shaikh AA. Knowledge and practices of primary health care physicians regarding updated guidelines of MERS-CoV infection in Abha city. Journal of family medicine and primary care. $2019 \mathrm{Feb} ; 8(2): 455$.

13. Imai $T$, Takahashi $K$, Hoshuyama $T$, Hasegawa N, Lim MK, Koh D. SARS risk perceptions in healthcare workers, Japan. Emerging Infectious Diseases. 2005 Mar;11(3):404.

How to cite this article: Suganya. P, Sindhu. R, Dhamodhar D et.al. Preparedness to tackle coronavirus and its risk perceptions among health care professionals in Chennai city, India a cross-sectional study. International Journal of Research and Review. 2021; 8(11): 227-233. DOI: https://doi.org/10.52403/ijrr.20211130 